\title{
Anionic Copolymerization of $p$-Anisaldehyde with Dimethylketene Initiated by Benzophenone-Dialkali Metal Complexes
}

\author{
Kazuhiko Hashimoto, Hiroshi Sumitomo, and Naoki Hayakawa \\ Faculty of Agriculture, Nagoya University, \\ Chikusa, Nagoya, Japan.
}

(Received January 22, 1974)

\begin{abstract}
The influence of alkali metal counter cations of initiators on the anionic copolymerization of $p$-anisaldehyde (ANA) with dimethylketene (DMK) in tetrahydrofuran at $-78^{\circ} \mathrm{C}$ was investigated. The copolymerization using benzophenonedisodium and -dipotassium complexes resulted in the formation of an ANA-DMK copolymer rich in DMK units, while the lithium complex gave the ANA-DMK alternating copolymer as previously reported. An obvious difference in the sequence distribution of the copolymers was detected by the NMR analysis.

KEY WORDS: Anionic Copolymerization / $p$-Anisaldehyde / Dimethylketene / Counter Cation / Ion Pair / Structural Analysis /
\end{abstract}

In the preceding study, ${ }^{1}$ the anionic copolymerization of $p$-anisaldehyde $\left(p-\mathrm{CH}_{3} \mathrm{O}-\mathrm{C}_{6} \mathrm{H}_{4}-\right.$ $\mathrm{CHO}$, ANA) with dimethylketene $\left(\left(\mathrm{CH}_{3}\right)_{2} \mathrm{C}=\right.$ $\mathrm{C}=\mathrm{O}$, DMK) initiated by benzophenonedilithium complex $\left(\mathrm{Li}_{2}-\mathrm{Bz} \mathrm{Ph}\right)$ was found to give an alternating copolymer (I) in such a polar solvent as tetrahydrofuran (THF).<smiles>COc1ccc(C(C)C)cc1</smiles>

I

The present investigation is concerned with the influence of alkali-metal counter cations of initiators on the anionic copolymerization of ANA with DMK.

\section{EXPERIMENTAL}

All procedures, including purification of materials, preparation of initiators, and polymerization, were carried out in a high-vacuum system as previously described. ${ }^{1-3}$ The average molecular weight of the copolymer, $\bar{M}_{n}$, was determined by the vapor-pressure osmometry (Hewlett Packard Model 302) in benzene at $37^{\circ} \mathrm{C}$. NMR spectra of the solution in deuterat- ed chloroform were taken with JNM-4H-100 and JNM-MH-100 spectrometers, using tetramethylsilane as a reference.

\section{RESULTS AND DISCUSSION}

Tables I and II summarize the results of the anionic copolymerization of ANA with DMK initiated by benzophenone-disodium $\left(\mathrm{Na}_{2}-\right.$ $\mathrm{BzPh})$ and -dipotassium $\left(\mathrm{K}_{2}-\mathrm{Bz} \mathrm{Ph}\right)$ complexes, respectively. The rate of copolymerization in the present systems was higher than that with $\mathrm{Li}_{2}$ BzPh. ${ }^{1}$ Because of the high rates of copolymerization especially in the range of higher mole fractions of DMK in the feed, an extremely small amount of the initiator had to be used in order to make the isolation of the copolymer at low conversions easier, at the sacrifice of the accuracy of the initiator concentration (about $\left.10^{-5} \mathrm{~mol} / l\right)$.

As shown in Figure 1, the compositions of Na-copolymer and K-copolymer (the ANADMK copolymers prepared by use of $\mathrm{Na}_{2}$ $\mathrm{BzPh}$ and $\mathrm{K}_{2}-\mathrm{BzPh}$, respectively) depend upon the monomer compositions, particularly in the lower range of mole fraction of ANA in the feed. Such a tendency was also observed in the copolymerization using sodium-naphthalene complex and sodium benzylate as initiators.

Table III gives the apparent values of mono- 


\section{K. Hashimoto, H. Sumitomo, and N. Hayakawa}

Table I. Anionic copolymerization of $p$-anisaldehyde with dimethylketene initiated by benzophenone-disodium complex ${ }^{a}$

\begin{tabular}{|c|c|c|c|c|c|c|c|}
\hline \multirow{2}{*}{$\begin{array}{l}\text { Exptl } \\
\text { no. }\end{array}$} & \multicolumn{3}{|c|}{ Monomer } & \multirow{2}{*}{$\begin{array}{l}\mathrm{Na}_{2}-\mathrm{BzPh}, \\
\text { mol\% } \\
\text { to monomer }\end{array}$} & \multirow{2}{*}{$\begin{array}{l}\text { Time, } \\
\text { sec }\end{array}$} & \multirow{2}{*}{$\begin{array}{c}\text { Polymer } \\
\text { yield, } \\
\%\end{array}$} & \multirow{2}{*}{$\begin{array}{c}\text { Mole fraction } \\
\text { of ANA } \\
\text { in } \\
\text { copolymerc }\end{array}$} \\
\hline & $\begin{array}{l}\text { ANA, } \\
\text { g }\end{array}$ & $\begin{array}{c}\text { DMK, } \\
\mathrm{g}\end{array}$ & $\begin{array}{l}\text { Mole fraction } \\
\text { of ANA }\end{array}$ & & & & \\
\hline 40 & 6.56 & 2.03 & $0.62_{5}$ & 0.03 & 50 & 14.3 & $0.46_{6}$ \\
\hline 30 & 5.26 & 2.56 & $0.51_{4}$ & 0.02 & 45 & 8.7 & $0.44_{9}$ \\
\hline $57^{\mathrm{d}}$ & 6.79 & 3.45 & $0.50_{3}$ & 0.06 & 60 & 76.0 & $0.45_{6}$ \\
\hline 39 & 1.78 & 1.43 & $0.39_{1}$ & - & 30 & 5.1 & $0.42_{4}$ \\
\hline $63^{d, e}$ & 1.46 & 1.41 & 0.34 & ca. 0.01 & 20 & 1.8 & $0.40_{8}$ \\
\hline 38 & 2.19 & 3.40 & $0.24_{9}$ & $<0.01$ & 30 & 1.2 & $0.36_{6}$ \\
\hline 29 & 1.35 & 2.87 & $0.19_{6}$ & 0.02 & 30 & 38.9 & $0.27_{1}$ \\
\hline $58^{d}$ & 1.41 & 3.46 & $0.17_{3}$ & ca. 0.01 & 30 & 75.7 & - \\
\hline 54 & 0.96 & 2.59 & $0.16_{1}$ & ca. 0.01 & ca. 10 & 65.5 & - \\
\hline
\end{tabular}

a Temp, $-78^{\circ} \mathrm{C}$; solvent, THF, $50 \mathrm{ml}$.

b Referred to the total weight of the monomers.

c Estimated from the peak intensity in the NMR spectrum.

d 100 parts of $\mathrm{NaBPh}_{4}$ were added to 1 part of the initiator.

- Initiator, $\mathrm{Li}_{2}-\mathrm{Bz} \mathrm{Ph}$.

Table II. Anionic copolymerization of $p$-anisaldehyde with dimethylketene initiated by benzophenone-dipotassium complex ${ }^{a}$

\begin{tabular}{|c|c|c|c|c|c|c|c|}
\hline \multirow{2}{*}{$\begin{array}{c}\text { Exptl } \\
\text { no. }\end{array}$} & \multicolumn{3}{|c|}{ Monomer } & \multirow{2}{*}{$\begin{array}{c}\mathrm{K}_{2}-\mathrm{BzPh} \\
\text { mol\% } \\
\text { to monomer }\end{array}$} & \multirow{2}{*}{$\begin{array}{c}\text { Time, } \\
\text { sec }\end{array}$} & \multirow{2}{*}{$\begin{array}{c}\text { Polymer } \\
\text { yield,b } \\
\%\end{array}$} & \multirow{2}{*}{$\begin{array}{c}\text { Mole fraction } \\
\text { of ANA } \\
\text { in } \\
\text { copolymer }\end{array}$} \\
\hline & $\begin{array}{l}\text { ANA, } \\
\mathrm{g}\end{array}$ & $\begin{array}{c}\text { DMK, } \\
\mathrm{g}\end{array}$ & $\begin{array}{l}\text { Mole fraction } \\
\text { of ANA }\end{array}$ & & & & \\
\hline 47 & 3.37 & 1.17 & $0.59_{6}$ & 0.04 & 30 & 9.5 & $0.48_{9}$ \\
\hline 59 & 6.88 & 3.19 & $0.52_{9}$ & 0.02 & 20 & 45.9 & 0.449 \\
\hline 46 & 4.55 & 3.58 & $0.39_{6}$ & ca. 0.01 & 30 & 5.7 & $0.43_{2}$ \\
\hline 60 & 2.88 & 2.96 & $0.33_{4} \times$ & ca. 0.01 & 20 & 29.9 & $0.41_{9}$ \\
\hline 49 & 2.75 & 3.58 & $0.28_{4}$ & $<0.01$ & 30 & 2.1 & $0.43_{2}$ \\
\hline 53 & 1.76 & 3.45 & $0.20_{7} \times$ & $<0.01$ & 40 & 2.4 & $0.41_{2}$ \\
\hline 61 & 1.47 & 3.49 & $0.17_{8}$ & $<0.01$ & 20 & 19.3 & $0.34_{3}$ \\
\hline
\end{tabular}

a Temp, $-78^{\circ} \mathrm{C}$; solvent, THF, $50 \mathrm{ml}$.

b Referred to the total weight of the monomers.

c Estimated from the peak intensity in the NMR spectrum.

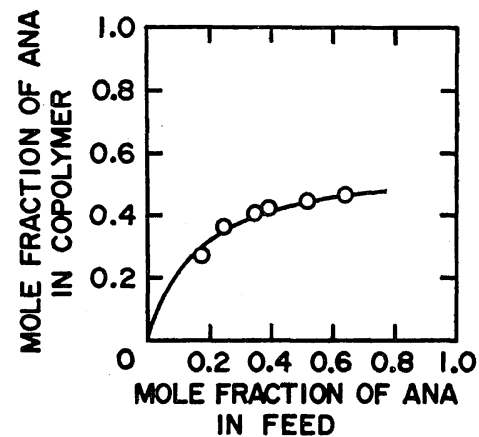

(A) Initiator, $\mathrm{Na}_{2}-\mathrm{Bz} \mathrm{Ph}$

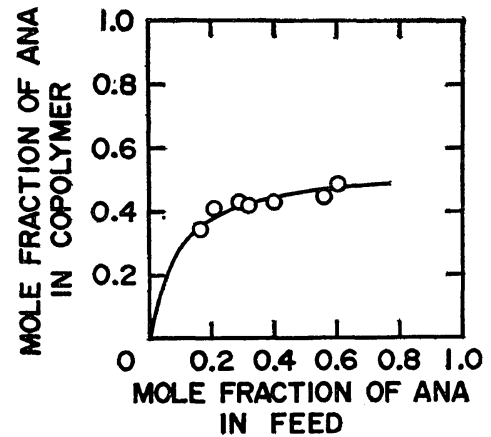

(B) Initiator, $\mathrm{K}_{2}-\mathrm{Bz} \mathrm{Ph}$

Figure 1. Copolymer composition curves of ANA-DMK copolymers: Condition, THF, $-78^{\circ} \mathrm{C}$. Curves were calculated from the values of (A) $r_{1}=0$ and $r_{2}=0.29$ and (B) $r_{1}=0$ and $r_{2}=0.16$ (ANA= monomer 1). 


\section{Anionic Copolymerization of $p$-Anisaldehyde}

Table III. Monomer reactivity ratios in copolymerization of ANA $\left(M_{1}\right)$ with DMK $\left(M_{2}\right)^{\text {a }}$

\begin{tabular}{lll}
\hline Initiator & \multicolumn{1}{c}{$r_{1}$} & \multicolumn{1}{c}{$r_{2}$} \\
\hline $\mathrm{Li}_{2}-\mathrm{BzPh}$ & 0 & 0 \\
$\mathrm{Na}_{2}-\mathrm{BzPh}$ & $0 \pm 0.04$ & $0.29 \pm 0.06$ \\
$\mathrm{~K}_{2}-\mathrm{BzPh}$ & $0 \pm 0.05$ & $0.16 \pm 0.05$
\end{tabular}

a Solvent, THF; polymerization temperature, $-78^{\circ} \mathrm{C}$.

mer reactivity ratios calculated by using the Mayo-Lewis integral scheme. These values reflect that the DMK-DMK diad in the copolymers increases with the change of counter cations of initiators from $\mathrm{Li}^{+}$to $\mathrm{Na}^{+}$or $\mathrm{K}^{+}$. As described later, this corresponds to the appearance of many methyl peaks from DMK units in NMR spectra of Na-copolymer and K-copolymer.

In the copolymerization initiated by $\mathrm{Na}_{2}$ $\mathrm{BzPh}$, an addition of a considerable amount of sodium tetraphenylboron $\left(\mathrm{NaBPh}_{4}\right)$ has no influence on the copolymer composition (Exptl no. 57 in Table I), which suggests little contribution of the free anion to the propagating species.

On the other hand the addition of $\mathrm{NaBPh}_{4}$ in the copolymerization initiated by $\mathrm{Li}_{2}-\mathrm{BzPh}$ (Exptl no. 63 in Table I) brought on the DMKrich copolymer just like the Na-copolymer, although the lithium complex without the addition of $\mathrm{NaBPh}_{4}$ gave the alternating copolymer (Licopolymer) as previously described. ${ }^{1}$ This fact shows as exchange of the counter cation in the growing ion pair from $\mathrm{Li}^{+}$to $\mathrm{Na}^{+}$.
Table IV gives the results of elution fractionation of the copolymers obtained in the present systems, together with the softening points and molecular weights. The softening point of the copolymers was not high, and increased with the mole fraction of ANA in the copolymer.

The infrared spectra of Na-copolymer and K-copolymer show characteristic absorption bands attributed to the ester group at 1735, 1250 , and $1120 \mathrm{~cm}^{-1}$ as well as that of the ANA-DMK alternating copolymer (Li-copolymer), which shows that the main structure of Na-copolymer and K-copolymer also consists of the same polyester type. However the variation with the copolymer composition was not clearly
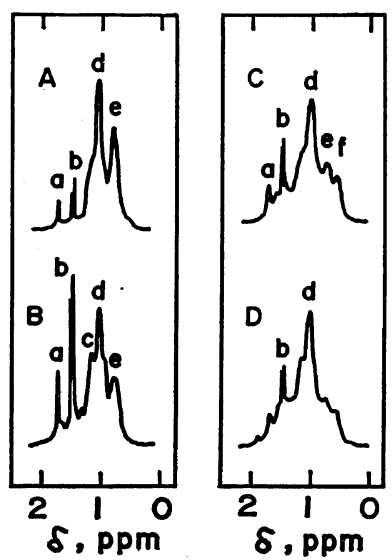

Figure 2. NMR spectra of ANA-DMK copolymers: (A), $\mathrm{Na}_{2}-\mathrm{Bz} \mathrm{Ph}, \quad x=0.42_{4} ;$ (B), $\mathrm{Na}_{2}-\mathrm{Bz} \mathrm{Ph}$, $x=0.36_{6} ; \quad(\mathrm{C}), \mathrm{K}_{2}-\mathrm{BzPh}, x=0.41_{2} ;(\mathrm{D}), \mathrm{K}_{2}-\mathrm{BzPh}$, $x=0.34_{3}$. Deuterated chloroform solution, $70^{\circ} \mathrm{C}$; $x$, mole fraction of ANA in copolymer.

Table IV. Results of elution fractionation of ANA-DMK copolymers

\begin{tabular}{|c|c|c|c|c|c|c|c|c|}
\hline \multirow{2}{*}{$\begin{array}{c}\text { Sample } \\
\text { no.a }\end{array}$} & \multirow{2}{*}{$\begin{array}{c}\text { Mole } \\
\text { fraction } \\
\text { of ANA } \\
\text { in feed }\end{array}$} & \multirow[b]{2}{*}{ Initiator } & \multirow{2}{*}{$\begin{array}{c}\text { Mole } \\
\text { fraction } \\
\text { of ANA } \\
\text { in copolymer }\end{array}$} & \multicolumn{3}{|c|}{ Benzene-soluble } & \multicolumn{2}{|c|}{ Benzene-insoluble } \\
\hline & & & & $\begin{array}{c}\text { Weight, } \\
\%\end{array}$ & $\begin{array}{l}\text { Softening } \\
\text { point, }{ }^{b}{ }^{\circ} \mathrm{C}\end{array}$ & $\bar{M}_{n}{ }^{\mathrm{c}}$ & $\begin{array}{c}\text { Weight, } \\
\%\end{array}$ & $\begin{array}{l}\text { Softening } \\
\text { point, }{ }^{\mathrm{b}}{ }^{\circ} \mathrm{C}\end{array}$ \\
\hline 57 & $0.50_{3}$ & $\mathrm{Na}_{2}-\mathrm{Bz} \mathrm{Ph}$ & $0.45_{6}$ & 78.1 & $144-167$ & 4800 & 21.9 & $145-199$ \\
\hline 29 & $0.19_{6}$ & $\mathrm{Na}_{2}-\mathrm{Bz} \mathrm{Ph}$ & $0.27_{1}$ & 100 & $109-122$ & 7800 & 0 & - \\
\hline 59 & $0.52_{9}$ & $\mathrm{~K}_{2}-\mathrm{Bz} \mathrm{Ph}$ & $0.44_{9}$ & 63.4 & $145-178$ & 4400 & 36.6 & $153-206$ \\
\hline 61 & $0.17_{8}$ & $\mathrm{~K}_{2}-\mathrm{BzPh}$ & $0.34_{3}$ & 98.6 & $113-124$ & 7900 & 1.4 & $119-143$ \\
\hline
\end{tabular}

a Sample numbers refer to products of experiments listed in Tables I and II.

b Observed through Yanagimoto microscopic melting point measuring apparatus.

c Vapor pressure osmometry in benzene at $37^{\circ} \mathrm{C}$. 
detected in their spectra.

On the other hand the NMR spectra of Nacopolymer and K-copolymer shown in Figure 2 represent clearly the variation of the copolymer structure with copolymer composition, where $x$ is the mole fraction of ANA in the copolymer, and with the counter metal cation.

In the NMR spectrum of the alternating $\mathrm{Li}$ copolymer (I), methyl protons give two peaks having the same intensity as each other at the $\delta$ values corresponding to peaks $\mathrm{d}$ and $\mathrm{e}$ in Figure $2^{1}$ which is due to the magnetic anisotropy of the polar groups surrounding the methyl protons. The many other methyl peaks due to the DMK unit appear in the spectra of Na-copolymer and K-copolpmer as given in Figure 2. The relative intensity of the peaks varies with the mole fraction of DMK in the copolymer.

As described by Natta, et al., ${ }^{4-6}$ and Yamashita, et al., ${ }^{7}$ DMK can polymerize through the opening of both $\mathrm{C}=\mathrm{C}$ and $\mathrm{C}=\mathrm{O}$ groups.<smiles>CC(C)(C)C=O</smiles>

II<smiles>COC(C)=C(C)C</smiles>

III
The many methyl peaks ascribed to the DMK unit in Figure 2 show that there are two different $\mathrm{DMK}$ units, $\mathrm{DMK}_{\mathrm{C}-\mathrm{C}}(\mathbf{I I})$ and $\mathrm{DMK}_{\mathrm{C}-\mathrm{O}}$ (III), also in the DMK-rich copolymers produced by $\mathrm{Na}_{2}-\mathrm{BzPh}$ and $\mathrm{K}_{2}-\mathrm{BzPh}$. The highly polyester-type homopolymer (IV) gives two peaks having a peak ratio of about $1: 3$ at the $\delta$ values corresponding to the peaks $a$ and $b$ in Figure $2 .^{3}$<smiles>CC(C)=C(C)C(C)(C)OC(=O)C(C)(C)C</smiles>

IV

From the viewpoint of the relative intensity of the peaks $a, b, d$, and $e$ in the spectra, the Na-copolymer should contain considerably longer blocks of the ANA-DMK $\mathrm{C}_{\mathrm{C}-\mathrm{C}}$ alternating unit and the $\mathrm{DMK}_{\mathrm{C}-\mathrm{O}}-\mathrm{DMK}_{\mathrm{C}-\mathrm{C}}$ alternating unit.
On the other hand, the NMR spectra of the $\mathrm{K}$-copolymer have broad peaks assignable to the presence of many methyl protons in various circumstances. Thus the copolymerization initiated by the potassium complex might give a more random copolymer also containing the other dyads, for example, ANA-DMK $\mathrm{C}_{\mathrm{C}-\mathrm{O}}$. This is supported by the fact that the exchange of counter cations of initiators from $\mathrm{Li}^{+}$to $\mathrm{Na}^{+}$or $\mathrm{K}^{+}$in the anionic homopolymerization of DMK brings on an increase of the $\mathrm{C}=\mathrm{O}$ opening of DMK. ${ }^{6,7}$

The electronegativity and the ionization potential suggest that the lithium ion-pair is more covalent than the sodium or potassium ion-pair. Stokes' radii determined by the study of electric conductivity ${ }^{8-10}$ show that $\mathrm{Li}^{+}$is solvated more strongly than $\mathrm{Na}^{+}$or $\mathrm{K}^{+}$, while anions are known to be scarcely solvated except in such polar protic solvents as water and alcohol. ${ }^{10,11}$ The solvation of the counter cations by monomers more polar than THF may be responsible for the selective addition of the monomers to the growing species and then structure of DMK sequence.

Aggregation of the propagating species, especially in the case of lithium, plays an important role on the anionic polymerization of nonpolar monomers such as styrene or conjugated dienes in nonpolar solvents. ${ }^{12-16}$ However in the present system consisting of polar monomers and solvent, such aggregation may be considered to be of little importance.

\section{REFERENCES}

1. K. Hashimoto and H. Sumitomo, J. Polym. Sci., Part A-1, 9, 1189 (1971).

2. H. Sumitomo and K. Hashimoto, ibid., Part $A-1,7,1331$ (1969).

3. K. Hashimoto and H. Sumitomo, Polymer J., 1, 190 (1970).

4. G. Natta, G. Mazzanti, and G. F. Pregaglia, Makromol. Chem., 44-46, 537 (1961).

5. G. Natta, G. Mazzanti, and G. F. Pregaglia, ibid., 51, 148 (1962).

6. G. F. Pregaglia, M. Binaghi, and M. Gambini, ibid., 67, 10 (1963).

7. Y. Yamashita and S. Nunomoto, Kogyo Kagaku Zasshi (J. Chem. Soc. Japan, Ind. Chem. Sect.), 66, 467 (1963). 


\section{Anionic Copolymerization of $p$-Anisaldehyde}

8. D. N. Bhattacharyya, C. L. Lee, J. Smid, and M. Szwarc, J. Phys. Chem., 69, 608 (1965).

9. C. Carvajal, K. J. Tölle, J. Smid, and M. Szwarc, J. Amer. Chem. Soc., 87, 5548 (1965).

10. B. J. Barker and J. A. Caruso, ibid., 93, 1341 (1971).

11. R. V. Slates and M. Szwarc, J. Phys. Chem., 69. 4124 (1965).

12. J. E. L. Roovers and S. Bywater, Can. J. Chem.,
46, 2711 (1968).

13. H. L. Lewis and T. L. Brown, J. Amer. Chem. Soc., 92, 4664 (1970).

14. M. Morton, T. J. Fetters, R. A. Pett, and J. F. Meier, Macromolecules, 3, 327 (1970).

15. W. Gebert, J. Hinz, and H. Sinn, Makromol. Chem., 144, 97 (1971).

16. D. J. Worsfold and S. Bywater, Macromolecules, 5, 393 (1972). 